• KOsnเn“• JIK. Vol. 2 No. 1 Maret 2014

\title{
HUBUNGAN POLA ASUH ORANG TUA DENGAN KEBIASAAN MEROKOK PADA REMAJA DI SMAN 1 POLANHARJO
}

\author{
Oleh : \\ Dinar Ariasti ${ }^{1}$ Budi Kristanto ${ }^{2}$ Ellen Morssy Tri Maharani ${ }^{3}$
}

\begin{abstract}
The background of this research is that the factors that influence adolescent smoking habits of parents are parenting, from the early observations researchers in October 2013 from 10 adolescents in SMAN 1 Polanharjo, 8 of them have the habit of smoking. Things that trigger their parents who smoke are smokers and who do not forbid parents to know that they smoke.

The purpose of this study was to determine the relationship of parenting parents to smoking in adolescents in SMAN 1 Polanharjo.

Subjects were male students of class XII at SMAN 1 Polanharjo IPS that about 40 people. After viewing the table Krecji, samples taken 36 people. The sampling technique used was simple random sampling.

The method of data collection was obtained by distributing a questionnaire containing 27 statements to determine parenting parents and three statements to find out the habit of smoking in adolescents. The data collected is then analyzed with the chi square test with $p=0.05$.

The results of the study are ( 1 ) found 1 person with parenting authotarian have the habit of smoking ( 2 ) 6 people with authoritative parenting does not have the habit of smoking, and ( 3 ) 29 people with permissive parenting has a habit of smoking. After the chi square test, $p$ obtained for 0000 so that the value of $p<0.05$, which means that $\mathrm{Ho}$ is rejected and $\mathrm{Ha}$ accepted.

Research conclusion is there is a relationship between parenting parents to smoking in adolescents in SMAN 1 Polanharjo .
\end{abstract}

Keywords: Parent Parenting, Smoking Habit

\section{PENDAHULUAN}

Masa remaja (adolescence) adalah masa perkembangan yang merupakan masa transisi dari anakanak menuju dewasa. Masa ini dimulai sekitar pada usia 10 hingga 12 tahun dan berakhir pada usia 18 hingga 21 tahun. Dalam menelusuri masa remaja, kita harus tetap mengingat bahwa tidak semua remaja sama. Etnis, budaya, sejarah, gender, sosial-ekonomi dan gaya hidup yang bervariasi, mewarnai lintasan kehidupan mereka. Bayangan kita mengenai masa remaja haruslah mempertimbangkan remaja tertentu atau sekelompok remaja yang kita pikirkan. (King, 2012)

Bagi remaja merokok adalah hal yang tidak asing lagi. Merokok cenderung mulai dilakukan ketika remaja duduk di kelas 7 hingga 9, meskipun cukup banyak anak muda yang mempertahankan kebiasaan merokok selama di sekolah menengah atas dan perguruan tinggi. Faktor-faktor resiko yang menjadikan perokok tetap di masa remaja adalah memiliki kawan yang merokok, orientasi akademik yang lemah, dan dukungan orang tua yang rendah. (Santrock, 2012) 
Menurut WHO, pada awal tahun 1990-an, 1,1 milyar orang menggunakan tembakau yang merepresentasikan sepertiga populasi penduduk dewasa di dunia. Saat ini, ada sekitar 1,3 milyar perokok di dunia, $84 \%$ berada di negara berkembang. Penggunaan tembakau di negara berkembang meningkat, sebanyak $48 \%$ pria dan $7 \%$ wanita menggunakan tembakau secara rutin. Di negara maju, penggunaan tembakau oleh perempuan mengalami peningkatan bermakna, 42\% laki-laki dan 24\% wanita menggunakan tembakau secara rutin. Anak-anak merokok 1.1 milyar paket rokok per tahunnya. Kebanyakan perokok melaporkan awal menggunakan tembakau pada masa kanak-kanak atau masa remaja, dengan $75 \%$ pengguna tembakau dewasa dilaporkan awal merokok ketika usia 11-17 tahun. Studi menyatakan rata-rata usia pertama kali merokok 14.5 tahun dan rata-rata usia perokok harian 17.7 tahun. Sekitar 20\% pelajar sekolah lanjutan atas merokok.Lebih dari $90 \%$, pertama kali merokok sebelum tamat sekolah lanjutan atas. (Syahdrajat, 2007)

Menurut Kristianti dan Wismanto, sebagaimana dikutip oleh Wismantono dan Sarwo (2007) menunjukkan bahwa orang tua yang merokok memiliki kecenderungan untuk permisif terhadap anak-anak remajanya yang merokok, daripada ayah yang tidak merokok. Hal tersebut dikarenakan orang tua yang merokok tidak memiliki "power" untuk melarang anaknya agar tidak merokok, karena dia sendiri juga merokok atau melakukan hal yang sama. Sedangkan orang tua yang tidak merokok mampu melarang anaknya untuk tidak merokok, karena dia sendiri juga tidak merokok dan memberi contoh yang baik.
Dari observasi awal yang peneliti lakukan di SMAN 1 Polanharjo pada bulan Oktober menunjukkan misalnya dari 10 remaja yang diwawancarai 8 diantaranya merokok. Hal yang memicu mereka merokok adalah orang tua yang perokok dan orang tua yang tidak melarang saat mengetahui bahwa mereka merokok.

\section{METODE PENELITIAN}

Penelitian ini merupakan penelitian analitik dengan desain korelasi untuk mengetahui hubungan antara pola asuh orang tua sebagai variabel bebas dengan kebiasaan merokok pada remaja sebagai variabel terikat.

Populasi dalam penelitian ini adalah siswa laki-laki kelas XII IPS di SMAN 1 Polanharjo yang berjumlah 40 orang. Dalam penelitian ini peneliti mengambil sampel dari para siswa laki-laki kelas XII IPS di SMAN 1 Polanharjo, yaitu sebanyak 36 orang. Jumlah tersebut peneliti ambil berdasarkan tabel krecjie, dimana jika jumlah populasi sebanyak 40 orang maka besar sampel adalah 36. Teknik sampling yang digunakan dalam penelitian ini adalah dengan sampel acak sederhana (simple random sampling) dengan cara mengundi sampel menggunakan nomor undian atau sesuai nomor secara acak.

Alat penelitian yang digunakan adalah kuesioner atau angket untuk mengetahui hubungan pola asuh orang tua dengan kebiasaan merokok pada remaja dengan jumlah pertanyaan 30 .

Dalam penelitian ini pengumpulan data dilakukan dengan metode penyebaran angket atau kuesioner dengan cara memberikan 30 pertanyaan kepada responden untuk mengetahui bagaimana pola asuh yang diterapkan orang tua dan kebiasaan merokok pada remaja. 


\section{HASIL PENELITIAN}

Hasil penelitian yang diperoleh terkait dengan pola asuh orang tua adalah sebagai berikut:

Tabel 1. Distribusi Frekuensi Pola Asuh Orang Tua di SMAN 1 Polanharjo

\begin{tabular}{|l|c|c|}
\hline \multicolumn{1}{|c|}{$\begin{array}{c}\text { Pola Asuh } \\
\text { Orang Tua }\end{array}$} & $\mathrm{F}$ & $\%$ \\
\hline Authotarian & 1 & 2,8 \\
\hline Authoritative & 6 & 16,7 \\
\hline Permisif & 29 & 80,6 \\
\hline Jumlah & 36 & $100 \%$ \\
\hline
\end{tabular}

Dari tabel di atas ditemukan ada 1 responden $(2,8 \%)$ berpola asuh authotarian, 6 responden (16,7\%) berpola asuh authoritative, 29 responden $(80,6 \%)$ berpola asuh permisif. Dapat dicermati bahwa persentase pada kategori pola asuh orang tua yang tinggi adalah $80,6 \%$ pada kategori pola asuh permisif. Sedangkan untuk kategori rendah hanya $2,8 \%$ pada kategori pola asuh authotarian. Hal ini membuktikan bahwa pola asuh orang tua yang permisif masih banyak.

Adapun hasil rata-rata kebiasaan merokok pada remaja di SMAN 1 Polanharjo adalah sebagai berikut :

Tabel 2. Distribusi Frekuensi Kebiasaan Merokok pada Remaja di SMAN 1 Polanharjo

\begin{tabular}{|l|c|c|}
\hline $\begin{array}{c}\text { Kebiasaan } \\
\text { Merokok }\end{array}$ & $\mathrm{F}$ & $\%$ \\
\hline Merokok & 30 & 83,3 \\
\hline $\begin{array}{l}\text { Tidak } \\
\text { Merokok }\end{array}$ & 6 & 16,7 \\
\hline Jumlah & 36 & $100 \%$ \\
\hline
\end{tabular}

Dari tabel diatas ditemukan 30 responden $(83,3 \%)$ merokok dan 6 responden $(16,7 \%)$ tidak merokok. Dapat disimpulkan bahwa kategori tinggi untuk kebiasaan merokok adalah $83,3 \%$ sedangkan untuk kategori rendah 16,7\%. Hal ini membuktikan bahwa kebiasaan merokok pada remaja di SMAN 1 Polanharjo tersebut masih tinggi.

Hasil analisa bivariat hubungan antara pola asuh orang tua dengan kebiasaan merokok pada remaja di SMAN 1 Polanharjo digambarkan pada tabel sebagai berikut:

Tabel 3. Tabulasi Silang Hubungan Pola Asuh Orang Tua dengan Kebiasaan Merokok pada Remaja di SMAN 1 Polanharjo

\begin{tabular}{|l|c|c|c|}
\hline \multirow{2}{*}{$\begin{array}{c}\text { Pola Asuh } \\
\text { Orang Tua }\end{array}$} & \multicolumn{3}{|c|}{$\begin{array}{c}\text { Kebiasaan } \\
\text { Merokok }\end{array}$} \\
\cline { 2 - 4 } & Ya & Tidak & Jmlh \\
\hline Authotarian & 1 & 0 & 1 \\
\hline Authoritative & 0 & 6 & 6 \\
\hline Permisif & 29 & 0 & 29 \\
\hline Jumlah & 30 & 6 & 36 \\
\hline
\end{tabular}

Dari tabel di atas peneliti menemukan bahwa dari 36 responden ditemukan 1 orang dengan pola asuh yang authoritarian, dan 1 orang tersebut memiliki kebiasaan merokok. Dari 36 responden ditemukan 6 orang dengan pola asuh yang authoritative, dan 6 orang tersebut tidak memiliki kebiasaan merokok. Dari 36 responden ditemukan 29 orang dengan pola asuh permisif, dan 29 orang tersebut memiliki kebiasaan merokok.

Dari hasil penelitian hubungan antara pola asuh orang tua dengan kebiasaan merokok pada remaja diperoleh hasil uji dengan ChiSquare program SPSS versi 18.0 dengan $\alpha=5 \%(0.05)$ diperoleh $p$ sebesar 0.000 sehingga nilai $\mathrm{p}<0.05$, yang berarti Ho ditolak dan Ha diterima, sehingga dapat ditarik kesimpulan bahwa ada hubungan antara pola asuh orang tua dengan kebiasaan merokok pada remaja di SMAN 1 Polanharjo. 


\section{PEMBAHASAN}

Persentase pada kategori pola asuh orang tua yang tinggi adalah $80.6 \%$ untuk pola asuh permisif. Sedangkan untuk kategori rendah hanya $2.8 \%$ untuk pola asuh autotharian. Hal ini membuktikan bahwa pola asuh orang tua permisif yang mendominasi, sehingga memicu remaja untuk merokok. Hal tersebut dapat terjadi karena dipengaruhi beberapa faktor baik dari pola asuh orang tua itu sendiri, pengaruh teman sebaya, pengaruh iklan juga faktor dari kepribadian. Faktor utama yang paling berperan adalah pola asuh orang tua, dari hasil penelitian ini pola asuh yang mendominasi perilaku merokok pada remaja adalah pola asuh permisif.

Menurut Septiari (2012), pola asuh permisif adalah pola asuh orang tua yang serba membolehkan anak berbuat apa saja. Orang tua memiliki kehangatan, dan menerima apa adannya. Kehangatan cenderung memanjakan, ingin dituruti keinginannya. Sedangkan menerima apa adanya cenderung memberikan kebebasan kepada anak untuk berbuat apa saja. Pola asuh ini dapat menyebabkan anak agresif, tidak patuh pada orang tua, sok kuasa, kurang mampu mengontrol diri.

Pola asuh orang tua yang permisif membuat remaja lebih agresif, tidak patuh pada orang tua dan kurang mampu mengontrol diri, hal-hal inilah yang memicu remaja untuk merokok. Karena kurangnya kontrol diri pada remaja membuat remaja mudah dipengaruhi dengan lingkungan sebayanya yang cenderung mempengaruhi remaja untuk merokok. Sedangkan dari pola asuh ini orang tua cenderung memberikan kebebasan kepada anak dan kontrol yang lemah pada anak-anak mereka, sehingga membuat remaja ini leluasa untuk merokok tanpa takut diketahui oleh orang tua.

Menurut Mu'tadin, sebagaimana dikutip oleh Amelia (2009), faktor penyebab remaja merokok adalah pengaruh orang tua, pengaruh teman, faktor kepribadian dan pengaruh iklan. Dari hasil penelitian yang dilakukan pada 36 responden di SMAN 1 Polanharjo didapati bahwa pengaruh orang tua lebih tepatnya pola asuh orang tua memberikan pengaruh yang cukup dominan untuk kebiasaan merokok pada remaja. Dari beberapa pola asuh, pola asuh permisif mendominasi kebiasaan merokok pada remaja, hasil penelitian pada 36 responden di SMAN 1 Polanharjo didapati 29 responden memiliki pola asuh orang tua yang permisif, dimana 29 responden tersebut memiliki kebiasaan merokok.

Persentase pada kategori merokok merupakan persentase tertinggi yaitu $83.3 \%$ atau sebanyak 30 responden yang memiliki kebiasaan merokok. Jadi dapat disimpulkan bahwa dari 36 mahasiswa di SMAN 1 Polanharjo, 30 diantaranya memiliki kebiasaan merokok.

Dari hasil penelitian Hubungan Antara Pola Asuh Orang Tua dengan Kebiasaan Merokok pada Remaja diperoleh hasil uji dengan Chi-Square program SPSS versi 18.0 dengan $\alpha=5 \%$ (0.05) diperoleh $p$ sebesar 0.000 sehingga nilai $\mathrm{p}<0.05$, yang berarti Ho ditolak dan Ha diterima, sehingga dapat ditarik kesimpulan bahwa ada hubungan antara pola asuh orang tua dengan kebiasaan merokok pada remaja di SMAN 1 Polanharjo. Pada siswa kelas XII IPS di SMAN 1 Polanharjo sebagian besar memiliki pola asuh yang permisif. Menurut Septiari (2012), pola asuh permisif adalah pola asuh yang membuat remaja lebih agresif, tidak patuh pada orang 
tua dan kurang mampu mengontrol diri, hal-hal inilah yang memicu remaja untuk merokok. Karena kurangnya kontrol diri pada remaja membuat remaja mudah dipengaruhi dengan lingkungan sebayanya yang cenderung mempengaruhi remaja untuk merokok. Sedangkan dari pola asuh ini orang tua cenderung memberikan kebebasan kepada anak dan kontrol yang lemah pada anak-anak mereka, sehingga membuat remaja ini leluasa untuk merokok tanpa takut diketahui oleh orang tua.

Penelitian yang dilakukan oleh peneliti pada siswa kelas XII di SMAN 1 Polanharjo didapati juga pola asuh yang paling rendah pengaruhnya terhadap kebiasaan merokok adalah pola asuh yang authoritative dengan hasil dari 36 responden, 6 responden memiliki pola asuh authoritative tidak memiliki kebiasaan merokok. Menurut Septiari (2012), pola asuh authoritative adalah pola asuh dimana orang tua sangat memperhatikan kebutuhan anak, dan mencukupi dengan pertimbangan faktor kepentingan dan kebutuhan. Pola asuh ini dapat mengakibatkan anak mandiri, mempunyai kontrol diri, mempunyai kepercayaan diri yang kuat, dapat berinteraksi dengan teman sebayanya dengan baik, mampu menghadapi stres, mempunyai minat terhadap hal-hal yang baru, kooperatif dengan orang dewasa, penurut, patuh, dan berorientasi pada prestasi. Sehingga dengan pola asuh authoritative ini, orang tua membekali anak kepercayaan diri yang kuat dan kontrol diri yang baik, dimana hal-hal diatas membuat remaja tidak mudah tergoda untuk memiliki kebiasaan merokok yang biasanya juga dipengaruhi oleh teman sebaya, iklan maupun faktor kepribadian.

\section{KESIMPULAN}

Dari hasil penelitian Hubungan Antara Pola Asuh Orang Tua dengan Kebiasaan Merokok pada Remaja diperoleh hasil uji dengan Chi-Square program SPSS versi 18.0 dengan $\alpha=5 \%$ (0.05) diperoleh $p$ sebesar 0.000 sehingga nilai $\mathrm{p}<0.05$, yang berarti Ho ditolak dan Ha diterima, sehingga dapat ditarik kesimpulan bahwa ada hubungan antara pola asuh orang tua dengan kebiasaan merokok pada remaja di SMAN 1 Polanharjo.

\section{SARAN}

1. Bagi Masyarakat

Diharapkan masyarakat dapat mengatasi kebiasaan merokok pada remaja dengan memberikan pengawasan untuk meminimalkan kebiasaan merokok pada remaja dan memberikan contoh perilaku yang sesuai kepada remaja untuk tidak memiliki kebiasaan merokok.

2. Bagi SMAN 1 Polanharjo

Diharapkan guru dan staf SMAN

1 Polanharjo untuk lebih memperhatikan dan membimbing siswa-siswanya yang mempunyai kebiasaan merokok untuk mengurangi bahkan menghentikan perilaku merokok.

3. Bagi Orang Tua

Diharapkan orang tua dapat memberikan pola asuh yang sesuai kepada anaknya untuk dapat mencegah perilaku merokok.

4. Bagi Peneliti Selanjutnya

Diharapkan untuk peneliti selanjutnya dapat melakukan penelitian yang berkaitan dengan kebiasaan merokok dalam lingkup yang lebih luas atau berhubungan dengan faktor lain. 
DAFTAR PUSTAKA

Chopra, Deepak. Fight Addictions. Jakarta: PT Bhuana IImu Populer, 2005.

Desmita. Psikologi Perkembangan. Bandung: PT Remaja Rosdakarya, 2010.

Hawari, Dadang. Penyalahgunaan dan Ketergantungan NAZA (Narkotika, Alkohol dan Zat Adiktif. Jakarta: Balai Penerbit FKUI, 2003.

Hidayat, A. Aziz Alimul. Riset Keperawatan dan Teknik Penulisan IImiah. Jakarta: Salemba Medika, 2008.

Metode Penelitian Keperawatan dan Teknik Analisis Data. Jakarta: Salemba Medika, 2009.

King, Laura K. Psikologi Umum. Jakarta: Salemba Humanika, 2012.

Proverawati, Atikah dan Eni Rahmawati. Perilaku Hidup Bersih dan Sehat (PHBS). Yogyakarta: Nuha Medika, 2012.

Riwidikdo, Handoko. Statistik untuk Penelitian Kesehatan. Yogyakarta: Pustaka Rihama, 2009.
Santrock, John W. Life-Span Development Perkembangan MasaHidup. Jakarta: PT Gelora Aksara Pratama, 2012.

Septiari, Bety Bea. Mencetak Balita Cerdas dan Pola Asuh Orang Tua. Yogyakarta: Nuha Medika, 2012.

Suyanto. Metodologi dan Aplikasi Penelitian Keperawatan. Yogyakarta: Nuha Medika, 2011.

Syahdrajat, Tantur. Dexa Media Jurnal Kedokteran dan Farmasi. Jakarta: Dexa Media, 2007.

Willis, Sofyan S. Remaja dan Masalahnya. Bandung: Alfabeta, 2005.

Wismanto, Bagus dan Budi Sarwo.Strategi Penghentian Perilaku Merokok. Semarang: Universitas Katolik Soegijapranata, 2007.

1 Dosen AKPER Panti Kosala Surakarta

2 Dosen AKPER Panti Kosala Surakarta

3 Mahasiswa AKPER Panti Kosala Surakarta 